\title{
高度下肢短縮を伴う内反股の観血的治療
}

\author{
鹿児島県立整肢園 \\ 大 迫 浩 文・肥 後勝 \\ 原田省 吾・川越 勝 秀
}

\section{Operative Treatment of Coxa Vara Deformity with Leg Length Discrepancy}

by

\author{
Hirofumi Osako, Masaru Higo, Shogo Harada \\ and Katsuhide Kawagoe \\ Kagoshima Prefectural Crippled Children's Hospital
}

\begin{abstract}
We report the experience of femoral lengthening with lowering of the greater trochanter in two cases. Femoral lengthening was performed by callus distraction using Orthofix. One case was a 13year-old male, the other was an 18-year-old female. They had histories of $\mathrm{CDH}$. Preoperative symptoms were limping, scoliosis and leg length discrepancy. Radiographically, coxa vara deformity and high greater trochanter were seen. Leg length discrepancy before operation were $42 \mathrm{~mm}$ in both cases. $45 \mathrm{~mm}$ and $35 \mathrm{~mm}$ lengthening was gained postoperatively. Limping and scoliosis were improved 10 months postoperatively. Femoral lengthening by callus distraction with lowering of the greater trochanter was a satisfactory procedure for coxa vara deformity with leg length discrepancy.
\end{abstract}

今回，我々は，先天性股関節脱臼の治療後に内反股 と下肢短縮を生じ，高度跛行を呈した 2 例の思春期症 例に対し, 大転子下降術と大腿骨仮骨延長術を併用し た治療経験を報告する。

$$
\text { 症例 }
$$

症例 1,13 才, 男児. 右先股脱で $\mathrm{Rb}$ により整復され たが,ペルテス様変化を生じた. 7 才時に頸部疲労骨折 のため骨頭の後内方転位と $2.5 \mathrm{~cm}$ の下肢長差を生 じ，三次元的骨切り術により変形矯正と骨痖合が得ら れたが, $2 \mathrm{~cm}$ の下肢長差が遺残した. 13 才時には跛行 と右下肢短縮が高度となった。入園時現症として, 軟 性，硬性墜下性の高度跛行， $4 \mathrm{~cm}$ の右下肢短縮，トレ ンデレンブルグ徵候，側弯を認めたが，股関節可動域 は良好であった。

術前の立位両大腿 X 線写真では，右大腿骨の 42 $\mathrm{mm}$ 短縮と右股関節の偏平骨頭，内反股，大転子高位

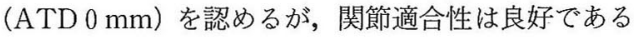

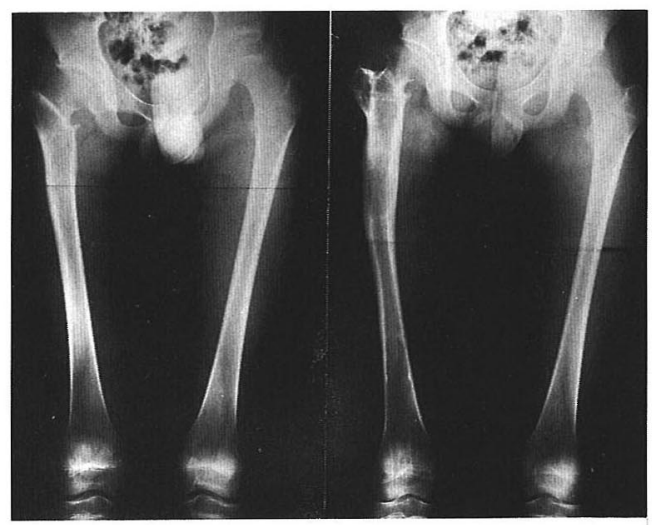

a)

b)

図 1 症例 1.13 才 男児

a ) 術前, 立位両大腿 X 線写真. 右大腿骨の 42 $\mathrm{mm}$ 短縮, 右内反股と大転子高位 (ATD $0 \mathrm{~mm}$ ) を認める。

b) 術後 10 力月 下肢等長, 大転子下降 (ATD $23 \mathrm{~mm}$ ), 右大腿骨の 9 度内反変形を認める. 
(図 1 -a)。また脊柱には立位で Th 9-L 4 で Cobb 角 $17^{\circ}$ の右凸の機能的胸腰椎側弯を認めた。

治療は, 外転筋群の筋力改善と下肢等長化のため大 転子下降術とOrthofix による大腿骨仮骨延長法を同 時併用し, さらに長内転筋と薄筋腱の切腱も行った。 近位骨幹部での仮骨延長法となったが，骨形成は良好 で $45 \mathrm{~mm}$ の大腿骨延長が得られた。骨延長には 126 日を要し, $1 \mathrm{~cm}$ あたりの骨延長日数は 28 日であった。 合併症としてピンのたわみによる $19^{\circ}$ の内反変形を骨 延長部に生じたが，リモデリングによりピン抜釬時に は $15^{\circ}$ となった。

骨延長終了 10 力月後の現在, 跛行, 下肢長差, 側弯 は消失し, 股関節可動域は正常でトレンデレンブルグ 徵候陰性である. X 線上, 下肢は等長となり, 大転子 は下降され (ATD $23 \mathrm{~mm}$ ), 右大腿骨の内反変形も $9^{\circ}$ に矯正されている (図 $1-b)$.

症例 2,18 才, 女子. 左先股脱で生後 8 力月時と 2 才 6 力月時に観血的に整復されるも再脱臼した. 11 才時, 再脱臼に対し, 観血的整復術・ $2 \mathrm{~cm}$ の減捻内反短縮骨 切り術・Chiari 骨盤骨切り術を併用し良好な求心位が 得られたが, $4 \mathrm{~cm}$ の左下肢短縮と跛行が遺残した. 18 才時より歩行後に左腎部の疲労感, 疼痛が出現してき た. 入園時現症として, 軟性, 硬性墜下性の高度跛行,

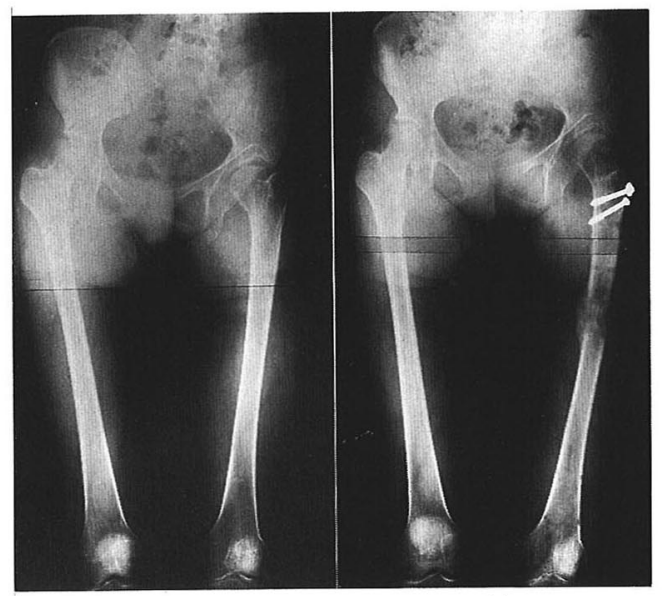

a)

b)

図 2 症例 2.18 才児 a ) 術前の立位両大腿 $X$ 線写真. 左内反股と左 大腿骨の $42 \mathrm{~mm}$ 短縮を認める (図 $2-a$ ). b) 術後 10 力月 左大腿骨 $7 \mathrm{~mm}$ 短縮と大転

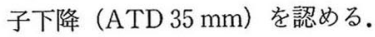

$4 \mathrm{~cm}$ の左下肢短縮, 左大腿筋筋萎縮, トレンデレンブ ルグ徵候, 側弯を認めたが，股関節可動域は良好であ った。補高装具の使用を嫌うため, 起立・歩行時に左 足部は尖足位を呈していた。

術前の立位両大腿 X 線写真では，左大腿骨の 42 $\mathrm{mm}$ 短縮を認めた。左股関節は適合性良好で関節裂隙 は保持され，臼蓋の被覆も良好であるが，内反股，大 転子高位（ATD $4 \mathrm{~mm}$ ) を認めた（図 2 -a). 立位脊 柱 X 線写真では Th $10-\mathrm{L} 4$ に Cobb 角 $21^{\circ}$ の左凸の 構築性胸腰椎側弯を認めた。治療は, 大転子下降術と Orthofix による大腿骨仮骨延長法を同時併用した。骨 膜が菲薄で, 骨切り後骨膜を十分に縫合できなかった ため仮骨出現が遅延し，骨形成も不良であったが，結 局 $35 \mathrm{~mm}$ の骨延長が得られた。骨延長には 157 日を 要し, $1 \mathrm{~cm}$ あたりの骨延長日数は 45 日であった。骨延 長終了後, 10 力月の現在, 疼痛なく, 歩行時に踵接地 可能となっているが, 軽度のトレンデレンブルグ跛行 がある.X 線写真上, ATD $35 \mathrm{~mm}$ と大転子は下降さ れ, 下肢長差も $7 \mathrm{~mm}$ に減少している（図 $2-\mathrm{b}$ ) が, 側弯は不変であった。

\section{考察およびまとめ}

先股脱の治療に対し，近年 $\mathrm{Rb}$ が用いられるように なりペルテス様変化の発生やそれによる遺残変形例も 少なくなってきた。しかし，骨頭成長軟骨に障害が加 わると内反股, 靧部短縮, 大転子高位などの変形を来 し，大腿骨短縮を合併することが多い。しかし，その 程度は比較的軽度であるが, 我々の 2 例はペルテス様 変化だけでなく骨切り術による直接的影響もあり, 約 $4 \mathrm{~cm}$ の下肢長差を生じたと考える。

内反股と下肢短縮に対する治療法として股関節外転 筋群の筋力改善と脚長差の調整を同時に得る方法が最 適と考えられ，諸家により種々の術式が報告されてき た。即時的骨延長の場合 $2 \mathrm{~cm}$ 程度の骨延長量に止ま る場合が多い.竹内ら は2², $3 \mathrm{~cm}$ 以上の下肢短縮例には 大腿骨漸次延長術が適応となるとし, 我々と同様な目 的で大転子下降術に Wagner 法を併用したが，この方 法では, 骨移植が必要となる. 我々の行った仮骨延長 法は, De Bastiani ${ }^{1)}$ の考案した強固な固定性を有する 延長器である Orthofix を用い, 骨切り後仮骨出現ま で一定の待機期間を置き，仮骨出現後 1 日 $1 \mathrm{~mm}$ ずつ の slow distraction を行い骨延長する方法である。骨 形成は，骨膜より骨間隙に供給された骨形成細胞の内 
軟骨性骨化によりなされるため骨膜の温存が重要であ る3) とされる.今回の症例 2 では骨切り後, 骨膜の縫合 ができず仮骨出現が遅延し，骨形成も不良であった。 しかし，仮骨延長法は，手術侵襲や合併症も少なく， 骨移植を必要としない有用な骨延長法である.

高度の下肢短縮を伴う内反股に対する治療法として の大転子下降術と大服骨仮骨延長法の併用法は, 関節 適合性に影響はなく，手術侵襲も比較的少なく，骨延 長量も大きく，外転筋力も改善される有用な観血的治 療法であると考える。しかし, 長期の治療期間を要す ることや, 関節適合性や被覆度に問題のある症例では,
股関節脱臼, 変形性股関節症の進展, 骨頭壊死などが 危惧されるなどの問題もあり, 慎重に適応を選ぶべき である。

\section{参 考 文 献}

1) De Bastiani G. et al : Limb lengthening by callus distraction (callotasis). J Pediatr. Orthop., 7: 129$134,1987$.

2）竹内一喜ら：脚短縮を伴う内反股に対する大転子下 降・大腿骨延長術。中部整災誌，23：107-110， 1980.

3）廣島和夫：脚延長の基礎。日整会誌，63：593-605, 1989. 